\title{
Formulation and In Vitro Evaluation of Sustained Release Floating Matrix Tablet of Levofloxacin by Direct Compression Method
}

\author{
Nidhi Kumari Pandey*1, Sailesh Kumar Ghatuary1, Amit Dubey1, Prabhat Kumar Jain ${ }^{2}$ \\ ${ }^{1}$ RKDF School of Pharmaceutical Science, Bhopal (M. P.) \\ ${ }^{2}$ Scan Research Laboratories, Bhopal (M. P.)
}

\begin{abstract}
The objective of the present work was to develop Gastro retentive dosage forms which would remain in the stomach and upper part or GIT for a prolonged period of time thereby maximizing the drug release at desired site within the time before GRDFs left the stomach and upper part of the GIT, has provoked a great deal of increased interest in the formulation of such drug as floating drug delivery systems. Levofloxacin, (BCS class I) is a fluoroquinolone anti-bacterial agent. The rationale for the formulation of floating matrix tablet are acidic solubility of levofloxacin, residence of Halicobactor pylori mainly in sub region of stomach and the overdosing associated adverse effect due to continuous intake of drug in acute infection. A simple visible spectrophotometric method was employed for the estimation of levofloxacin at $294 \mathrm{~nm}$ and Beer's law is obeyed in the concentration range of $2-10 \mu \mathrm{g} / \mathrm{ml}$. Floating matrix tablet of levofloxacin was prepared by direct compression method using different polymers like hydroxyl propyl methyl cellulose (HPMC K4) and carbopol 934 as matrix formation polymers, sodium bicarbonate and citric acid was used as gas generating agents. The FTIR spectra of the levofloxacin and other excipients alone and in combination show the compatibility of the drug and excipients. Six formulations of different polymer percentages were formulated (F1-F6). Pre-compression parameters were evaluated. The influence of matrix forming agents and binary mixtures of them on levofloxacin release was investigated. The formulated tablets were characterized by hardness, friability, thickness, weight variation and in vitro drug release. The formulated tablets had acceptable physicochemical characters. The data obtained from the in-vitro dissolution studies of optimized batch F4were fitted in different models. The optimized formulation F4 showed $99.25 \%$ drug content and swelling index of $79.85 \%$. Drug release mechanism was found to be first order kinetics. Levofloxacin floating tablets exhibited increased gastric residence time, there by improved bioavailability and therapeutic effect of the drug.
\end{abstract}

Keywords: Levofloxacin, Gastro retentive, Hydroxy propyl methyl cellulose, Carbopol, Halicobactor pylori, Direct compression method

Article Info: Received 11 June 2019; $\quad$ Review Completed 23 July 2019; $\quad$ Accepted 28 July 2019; Available online 15 August 2019

Cite this article as:

Pandey NK, Ghatuary SK, Dubey A, Jain PK, Formulation and In Vitro Evaluation of Sustained Release Floating Matrix Tablet of Levofloxacin by Direct Compression Method, Journal of Drug Delivery and Therapeutics. 2019; 9(4-s):398-403 http://dx.doi.org/10.22270/jddt.v9i4-s.3345

*Address for Correspondence:

Nidhi Kumari Pandey, RKDF School of Pharmaceutical Science, Bhopal (M. P.)

\section{INTRODUCTION}

Floating drug delivery system (FDDS) shows buoyancy in stomach for extended time period thus offers extended gastric residence time for the dosage form ensuring optimal bioavailability (BA) ${ }^{1}$. The residence time of the dosage form in the stomach depends upon various factors like $\mathrm{pH}$, size of the dosage form, food intake, and biological factors which include age, body mass index, gender, posture, and diseased states (hepatic failure, diabetes, chrons disease). Other techniques for gastro retentive dosage forms involve swelling, mucoadhesion, sedimentation, microballoons 2,3 and low density systems. Out of all systems available, the floating beads, floating tablets and floating microspheres have gained major importance. FDDS possess lower bulk density than the gastric fluid exerting buoyancy in the stomach leading to slow drug release in an extended manner before it reaches absorption window 4 . In this present formulation, dual benefits of buoyancy as well as sustained action are achieved with an intention to maintain the steady state of drug release ${ }^{5}$. Hydrophilic matrix system is one of the easiest approaches for developing modified and sustained release dosage forms. A polymer like hydroxyl propyl methyl cellulose (HPMC) function as a $\mathrm{pH}$ independent gelling agent and drug release is shown by swelling and erosion mechanism occurring simultaneously contributing to overall drug release ${ }^{6}$. Matrix system is the commonly used method for modulating the drug release? The manufacture of matrix tablets by direct compression is cheaper, simpler process, broad regulatory acceptance, and allows flexibility in obtaining desirable release profiles ${ }^{8}$. Levofloxacin is a synthetic chemotherapeutic antibiotic of the 
fluoroquinolone drug class and is used to treat severe or lifethreatening bacterial infections or bacterial infections that have failed to respond to other antibiotic classes9. Levofloxacin is a broad-spectrum antibiotic, inhibiting DNA gyrase, a type II topoisomerase, and topoisomerase IV, which is an enzyme necessary to separate replicated DNA, thereby inhibiting cell division ${ }^{10}$. The bioavailability of levofloxacin is above $99 \%$ with a plasma half-life of 6-8 h. It is freely soluble in $\mathrm{pH} 0.6$ to 5.8 ranges. Above $\mathrm{pH} 5.8$, the solubility increases rapidly to its maximum at $\mathrm{pH} 6.7$ and above which the solubility decreases and reaches a minimum value at a $\mathrm{pH}$ of approximately 6.9. Thus solubility of the drug is reduced in intestinal alkaline $\mathrm{pH}^{11}$ hence, it was selected in the present investigation as a suitable candidate for the design of gastric floating drug delivery system for improved retention time and bioavailability. The present study is to develop a floatable drug delivery system of levofloxacin using hydroxy propyl methyl cellulose, carbopol for sustained drug delivery and gastric retentive property. Thus the study aims to improve the oral bioavailability of the drug and to achieve extended retention in the stomach which may result in prolonged absorption.

\section{MATERIALS AND METHODS}

\section{Materials}

Levofloxacin was received as a gift sample from Ajanta Pharmaceuticals, Mumbai. Hydroxy Propyl Methylcellulose, Magnesium stearate, Sodium bicarbonate, Talc, Carbopol, were procured from S. D. Fine Chem. Ltd, Mumbai, India. All other solvents and reagents were purchased from Merck (Germany) and were of analytical grade.

\section{Methods}

\section{Determination of $\lambda_{\max }$ of levofloxacin}

The $\lambda_{\max }$ of levofloxacin was determined by analyzing the drug solution in double beam ultraviolet spectrophotometer.
Accurately weighed $10 \mathrm{mg}$ of drug was dissolved in $10 \mathrm{ml}$ of $0.1 \mathrm{~N} \mathrm{HCl}$ solutions in $10 \mathrm{ml}$ of volumetric flask. The resulted solution was $1000 \mu \mathrm{g} / \mathrm{ml}$ of strength and from this solution 1 $\mathrm{ml}$ solution was pipette out and transfer into $10 \mathrm{ml}$ capacity of volumetric flask and volume was made upto $10 \mathrm{ml}$ with $0.1 \mathrm{~N} \mathrm{HCl}$ solutions. This solution was scan at wavelength 400-200 nm on UV spectrophotometer. The higher absorption peak was obtained at $294 \mathrm{~nm}$ which was the $\lambda_{\max }$ of drug.

\section{Preparation of calibration curve of levofloxacin}

Previously prepared stock solution $(1000 \mu \mathrm{g} / \mathrm{ml}$ of strength) of Levofloxacin was use to prepare suitable dilution into concentration range of $2-10 \mu \mathrm{g} / \mathrm{ml} .0 .2,0.4,0.6,0.8$ and 1.0 $\mathrm{ml}$ of solution was taken in different volumetric flask having $10 \mathrm{ml}$ of capacity and dilute upto $10 \mathrm{ml}$ with $0.1 \mathrm{~N} \mathrm{HCl}$ to obtained 2, 4, 6, 8 and $10 \mu \mathrm{g} / \mathrm{ml}$ of solution. The absorbance of these solutions was taken at $294 \mathrm{~nm}$ using UVspectrophotometer (Labindia-3000 Plus). Graph between absorbance and concentration was plotted followed linearly regressed on Microsoft excel.

\section{Preparation of floating tablets of levofloxacin}

Levofloxacin matrix floating tablets were prepared by direct compression method employing sodium bicarbonate as gasgenerating agent. HPMC and Carbopol were used as rate controlling polymers. The concentrations of the excipients were optimized as showed in table 1 . The drug was mixed with the rate retarding polymers and other excipients in ascending order of their weights. The powder mix was blended for $20 \mathrm{~min}$ to have uniform distribution of drug in the formulation. Then magnesium Stearate and Talc were added. About $450 \mathrm{mg}$ of the powder mix was weighed accurately and fed into the die and compressed using $10 \mathrm{~mm}$ round surface punches ${ }^{12}$. The composition of formulation was given in table 1.

Table 1Composition of SR matrix floating tablet of levofloxacin

\begin{tabular}{|c|c|c|c|c|c|c|}
\hline Excipients(mg) & F1 & F2 & F3 & F4 & F5 & F6 \\
\hline Levofloxacin & 250 & 250 & 250 & 250 & 250 & 250 \\
\hline HPMC K 4 & 80 & 90 & 100 & 80 & 90 & 100 \\
\hline Carbopol & 20 & 20 & 20 & 30 & 30 & 30 \\
\hline NaHCO $_{3}$ & 15 & 15 & 15 & 15 & 15 & 15 \\
\hline $\mathbf{M g}\left(\mathbf{C}_{\mathbf{1 8}} \mathbf{H}_{\mathbf{3}} \mathbf{O}_{\mathbf{2}} \mathbf{)}_{\mathbf{2}}\right.$ & 15 & 15 & 15 & 15 & 15 & 15 \\
\hline Talc & 15 & 15 & 15 & 15 & 15 & 15 \\
\hline Lactose & 55 & 45 & 35 & 45 & 35 & 25 \\
\hline Total Weight & 450 & 450 & 450 & 450 & 450 & 450 \\
\hline
\end{tabular}

\section{Evaluation of levofloxacin floating matrix tablets}

\section{Pre-compression parameters}

\section{Angle of repose}

The angle of repose of blends was determined by the funnel method. The accurately weighed blend was taken in the funnel. The height of the funnel was adjusted in such a way that the tip of the funnel just touched the apex of the heap of the blend. The blend was allowed to flow from the funnel on the surface. The diameter and height of the heap formed from the blend were measured. The angle of repose was calculated using the following formula ${ }^{13}$.

\section{$\operatorname{Tan} \theta=h / r$}

Where, " $h$ " is the height of the heap and " $r$ " is the radius of the heap of granules.

\section{Bulk density (BD)}

An accurately weighed powder blend from each formula was lightly shaken to break any agglomerates formed and it was introduced in to a measuring cylinder. The volume occupied by the powder was measured which gave bulk volume. The BD of powder blends was determined using the following formula 14 .

Bulk density $=$ Total weight of powder $/$ Total volume of powder

\section{Tapped bulk density (TBD)}

An accurately weighed powder blend from each formula was lightly shaken to break any agglomerates formed and it was introduced into a measuring cylinder. The measuring cylinder was tapped until no further change in volume was 
noted which gave the tapped volume. The TBD of powder blends was determined using the following formula15.

TBD $=$ Total weight of powder/Total volume of tapped powder

\section{Carr's compressibility index}

The Carr's compressibility index was calculated from bulk density (BD) and tapped density of the blend. A quantity of 2 $\mathrm{g}$ of blend from each formulation, filled into a $10 \mathrm{ml}$ of measuring cylinder. Initial bulk volume was measured, and cylinder was allowed to tap from the height of $2.5 \mathrm{~cm}$. The tapped frequency was $25 \pm 2 /$ min to measure the tapped volume of the blend. The BD and tapped density were calculated by using the bulk volume and tapped volume.

Carr's compressibility index was calculated using the following formula16,17.

Carr's compressibility index $(\%)=[($ Tapped density-Bulk density) $\times 100] /$ Tapped density

\section{Hausner's ratio}

It is the measurement of frictional resistance of the drug. The ideal range should be $1.2-1.5$, it was determined by the ratio of tapped density and bulk density.

HR = Tapped Density/ Bulk Density

\section{Post-compression parameters}

\section{Shape of tablet}

Directly compressed tablets were examined under the magnified lens for the shape of the tablet.

\section{Thickness}

Twenty tablets from the representative sample were randomly taken and individual tablet thickness was measured by using digital vernier caliper ${ }^{18}$.

\section{Hardness}

Tablet hardness was measured by using Monsanto hardness tester. From each batch six tablets were measured for the hardness and average of six values was noted along with standard deviations.

\section{Friability test}

From each batch, ten tablets were accurately weighed and placed in the friability test apparatus (Roche friabilator). Apparatus was operated at 25 rpm for 4 minutes and tablets were observed while rotating. The tablets were then taken after 100 rotations, de dusted and reweighed. The friability was calculated as the percentage weight loss.

$\%$ friability was calculated as follows

$\%$ Friability $=(\mathrm{W} 1-\mathrm{W} 2) \times 100 / \mathrm{W} 1$

Where $\mathrm{W} 1$ = Initial weight of the 10 tablets, $\mathrm{W} 2=$ Final weight of the 10 tablets after testing.

Friability values below $0.5-1 \%$ are generally acceptable [19].

\section{Weight variation test}

To study weight variation individual weights (WI) of 20 tablets from each formulation were noted using electronic balance. Their average weight (WA) was calculated. Percent weight variation was calculated as follows. Average weights of the tablets along with standard deviation values were calculated.

\section{Swelling index}

Swelling study of individual polymers and combinations was carried out using eight-stage USP type 1 (basket) Dissolution Test Apparatus (Lab India, DS 8000) at $50 \mathrm{rpm}$, and $0.1 \mathrm{~N} \mathrm{HCl}$ was used as medium, and the temperature was maintained at $37 \pm 0.5^{\circ} \mathrm{C}$. Weight of individual tablet was taken prior to the swelling study $\left(\mathrm{W}_{1}\right)$. The tablet was kept in a basket. The weight of tablet was taken at time interval of 2, 4, 8, 12 hours $\left(\mathrm{W}_{2}\right)$. Percent hydration (swelling index) was calculated as shown in Table using the following formula:

Swelling index $=\left(\mathrm{W}_{2}-\mathrm{W}_{1}\right) \times 100 / \mathrm{W}_{2}$,

Where $W_{1}$ is the initial weight of tablet and $W_{2}$ is the weight of hydrated tablet

\section{Drug content}

Twenty tablets were taken and amount of drug present in each tablet was determined. The tablets were crushed in a mortar and the powder equivalent to $10 \mathrm{mg}$ of drug was transferred to $10 \mathrm{ml}$ standard flask. The powder was dissolved in $5 \mathrm{ml}$ of $0.1 \mathrm{~N} \mathrm{HCl}$ and made up to volume with of $0.1 \mathrm{~N} \mathrm{HCl}$. The sample was mixed thoroughly and filtered through a $0.45 \mu$ membrane filter. The filtered solution was diluted suitably and for drug content by UV spectrophotometer at $\lambda$ max of $294 \mathrm{~nm}$ using of $0.1 \mathrm{~N} \mathrm{HCl}$ as blank.

\section{Dissolution rate studies}

In vitro drug release of the sample was done using USP-type II dissolution apparatus (Paddle type). The dissolution medium, $900 \mathrm{ml} 0.1 \mathrm{~N} \mathrm{HCl}$ was set into the dissolution flask maintaining the temperature of $37 \pm 0.5^{\circ} \mathrm{C}$ and rpm of 75 . One levofloxacin tablet was set in every container of dissolution apparatus. The mechanical assembly was permitted to keep running for 10 hours. Sample measuring $5 \mathrm{ml}$ were pulled back after each 1 hour up to 2 hours using $10 \mathrm{ml}$ pipette. The new disintegration medium $\left(3^{\circ} \mathrm{C}\right)$ was supplanted each time with a similar amount of the sample and takes the absorbance at $294.0 \mathrm{~nm}$ using spectroscopy.

\section{Kinetic analysis of dissolution data}

To analyze the in vitro release data various kinetic models were used to describe the release kinetics. The zero order rate Eq. (1) describes the systems where the drug release rate is independent of its concentration. The first order Eq. (2) describes the release from system where release rate is concentration dependent. Higuchi (1963) described the release of drugs from insoluble matrix as a square root of time dependent process based on Fickian diffusion Eq. (3). The Hixson-Crowell cube root law Eq. (4) describes the release from systems where there is a change in surface area and diameter of particles or tablets.

$\mathrm{C}=\mathrm{K} 0 \mathrm{t}$

Where, K0 is zero-order rate constant expressed in units of concentration/time and $t$ is the time.

$\log C=\log C 0-\mathrm{K} 1 \mathrm{t} / 2.303$

Where, $\mathrm{C} 0$ is the initial concentration of drug and $\mathrm{K} 1$ is first order constant.

$\mathrm{Q}=\mathrm{KHt} 1 / 2$

Where, $\mathrm{KH}$ is the constant reflecting the design variables of the system.

$\mathrm{Q} 01 / 3-\mathrm{Qt} 1 / 3=\mathrm{KHC} \mathrm{t}$ 
Where, Qt is the amount of drug remained in time $t, \mathrm{Q} 0$ is the initial amount of the drug in tablet and $\mathrm{KHC}$ is the rate constant for Hixson-Crowell rate equation.

The following plots were made using the in-vitro drug release data

Cumulative \% drug release vs. time (Zero order kinetic model); Log cumulative of \% drug remaining vs. time (First order kinetic model); Cumulative $\%$ drug release vs. square root of time

(Higuchi model); and cube root of initial concentration minus the cube root of percentage of drug remaining in the matrix vs. time (Hixson-Crowell cube root law) ${ }^{20}$.

\section{RESULTS AND DISCUSSION}

$\lambda$ max of levofloxacin was found to be $294 \mathrm{~nm}$ by using U.V. spectrophotometer ((Labindia-3000 Plus)) in linearity range $2-10 \mu \mathrm{g} / \mathrm{ml}$ Fig.1.

Tablet powder blend was subjected to various precompression parameters Table 2 . The angle of repose values indicates that the powder blend has good flow properties. The bulk density of all the formulations was found to be in the range of 0.428 to $0.439(\mathrm{gm} / \mathrm{ml})$ showing that the powder has good flow properties. The tapped density of all the formulations was found to be in the range of 0.531 to 0.548 showing the powder has good flow properties. The compressibility index of all the formulations was found to be ranging between 18.704 to 20.438 which show that the powder has good flow properties. All the formulations have shown the Hauser's ratio ranging between 1.230 to 1.257 indicating the powder has good flow properties.

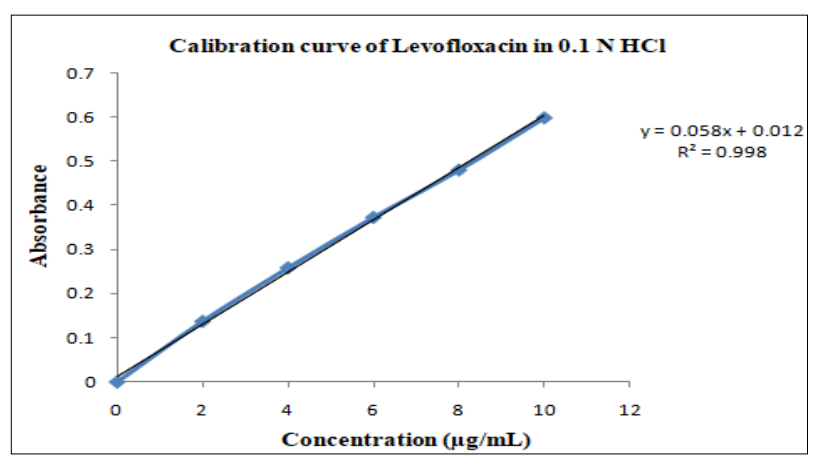

Figure 1 Calibration curve of levofloxacin in $0.1 \mathrm{~N} \mathrm{HCl}$ at 294nm

Table 2 Result of pre-compression properties of levofloxacin GR tablets

\begin{tabular}{|c|c|c|c|c|}
\hline F. Code & $\begin{array}{c}\text { Bulk } \\
\text { density }(\mathbf{g m} / \mathbf{m l})\end{array}$ & $\begin{array}{c}\text { Tapped } \\
\text { density }(\mathbf{g m} / \mathbf{m l})\end{array}$ & $\begin{array}{c}\text { Compressibility } \\
\text { index }\end{array}$ & $\begin{array}{c}\text { Hausner's } \\
\text { ratio }\end{array}$ \\
\hline F1 & 0.432 & 0.539 & 19.852 & 1.248 \\
\hline F2 & 0.441 & 0.543 & 18.785 & 1.231 \\
\hline F3 & 0.436 & 0.548 & 20.438 & 1.257 \\
\hline F4 & 0.432 & 0.536 & 19.403 & 1.241 \\
\hline F5 & 0.439 & 0.540 & 18.704 & 1.230 \\
\hline F6 & 0.428 & 0.531 & 19.397 & 1.241 \\
\hline
\end{tabular}

The results of post-compression parameters such as the uniformity of weight, hardness, thickness, friability, swelling index and disintegration time of the tablets are given in Table 3. All the tablets of different batches complied with the official requirements of uniformity of weight. The hardness of the tablets ranged from $5.1 \pm 0.3$ to $5.6 \pm 0.1 \mathrm{~kg} / \mathrm{cm}^{2}$ and the friability values were less than $0.9 \%$ indicating that the matrix tablets were compact and hard. The thickness of the tablets ranged from 3.21 to $3.45 \mathrm{~mm}$. All the formulations satisfied the content of the drug as they contained 98.78 to $99.56 \%$ of levofloxacin and good uniformity in drug content was observed. Thus all the physical attributes of the prepared tablets were found be practically within control.

Table 3 Results of post compression properties of levofloxacin FGR tablets

\begin{tabular}{|c|c|c|c|c|c|}
\hline F. code & $\begin{array}{c}\text { Thickness } \\
\mathbf{( m m )}\end{array}$ & $\begin{array}{c}\text { Hardness (kg/cm2) } \\
\mathbf{n = 3}\end{array}$ & $\begin{array}{c}\text { Weight variation (mg) } \\
\mathbf{n = 3}\end{array}$ & $\begin{array}{c}\text { Friability (\%) } \\
\mathbf{n = 3}\end{array}$ & $\begin{array}{c}\text { Drug content (\%) } \\
\mathbf{n = 3}\end{array}$ \\
\hline F1 & 3.25 & $5.2 \pm 0.2$ & $445 \pm 5$ & $0.898 \pm 0.025$ & $99.22 \pm 0.022$ \\
\hline F2 & 3.26 & $5.4 \pm 0.2$ & $455 \pm 4$ & $0.852 \pm 0.023$ & $98.89 \pm 0.021$ \\
\hline F3 & 3.45 & $5.6 \pm 0.1$ & $450 \pm 6$ & $0.987 \pm 0.014$ & $99.56 \pm 0.026$ \\
\hline F4 & 3.25 & $5.5 \pm 0.3$ & $452 \pm 5$ & $0.569 \pm 0.015$ & $99.25 \pm 0.041$ \\
\hline F5 & 3.22 & $5.2 \pm 0.2$ & $442 \pm 4$ & $0.852 \pm 0.021$ & $98.78 \pm 0.032$ \\
\hline F6 & 3.21 & $5.1 \pm 0.3$ & $440 \pm 3$ & $0.745 \pm 0.015$ & $99.12 \pm 0.025$ \\
\hline
\end{tabular}

Swelling study of individual polymers and combinations was carried out using eight-stage USP type 1 (basket) Dissolution Test Apparatus (Lab India, DS 8000) at $50 \mathrm{rpm}$, and $0.1 \mathrm{~N}$ $\mathrm{HCl}$ was used as medium, and the temperature was maintained at $37 \pm 0.5^{\circ} \mathrm{C}$. Results was given in table 4
Table 4 Results of swelling index of levofloxacin matrix tablets

\begin{tabular}{|c|c|c|c|c|}
\hline \multirow{2}{*}{ F. Code } & \multicolumn{4}{|c|}{ \% Swelling Index } \\
\cline { 2 - 5 } & 2 hrs. & 4 hrs. & 8hrs. & 12hrs. \\
\hline F1 & 22.36 & 43.56 & 63.25 & 73.25 \\
\hline F2 & 24.36 & 44.58 & 68.89 & 75.65 \\
\hline F3 & 23.45 & 43.36 & 65.52 & 74.58 \\
\hline F4 & 28.89 & 54.57 & 69.98 & 79.85 \\
\hline F5 & 29.45 & 55.45 & 70.23 & 80.21 \\
\hline F6 & 26.45 & 56.74 & 72.45 & 78.25 \\
\hline
\end{tabular}


The tablets were evaluated for in vitro dissolution studies in Phosphate buffer $0.1 \mathrm{~N} \mathrm{HCl}$ for 12 hrs. The results of the optimized formulation $\mathrm{F} 4$ showed maximum drug release i.e. $98.78 \%$ at the end of $12 \mathrm{hrs}$. The results of release studies of formulations F4 was shown in Table 5 \& Fig 2. The in vitro drug release data of the optimized formulation F4 was subjected to goodness of fit test by linear regression analysis according to zero order, first order kinetic equation, Higuchi's and Korsmeyer's models in order to determine the mechanism of drug release. When the regression coefficient values of were compared, it was observed that ' $r$ ' values of first order was maximum i.e. 0.989 hence indicating drug release from formulations was found to follow first order release kinetics Table 6 \& Fig 3-6.

Table 5 In-vitro drug release study of GRF tablets

\begin{tabular}{|c|c|c|c|c|c|c|}
\hline Time & \multicolumn{7}{|c|}{ \% Cumulative Drug Release } \\
\hline (hr) & F1 & F2 & F3 & F4 & F5 & F6 \\
\hline 0.5 & 33.25 & 32.25 & 30.14 & 25.56 & 20.36 & 18.56 \\
\hline 1 & 45.56 & 40.23 & 39.98 & 32.25 & 26.65 & 22.25 \\
\hline 1.5 & 65.56 & 60.58 & 59.88 & 46.69 & 40.23 & 39.98 \\
\hline 2 & 88.89 & 79.98 & 78.89 & 58.89 & 51.12 & 49.98 \\
\hline 3 & 98.89 & 87.52 & 85.56 & 69.98 & 60.23 & 55.56 \\
\hline 4 & - & 93.32 & 92.23 & 76.12 & 71.45 & 69.78 \\
\hline 6 & - & 98.85 & 99.12 & 88.56 & 79.98 & 78.89 \\
\hline 8 & - & - & - & 92.23 & 86.65 & 83.32 \\
\hline 12 & - & - & - & 98.78 & 90.12 & 89.98 \\
\hline
\end{tabular}

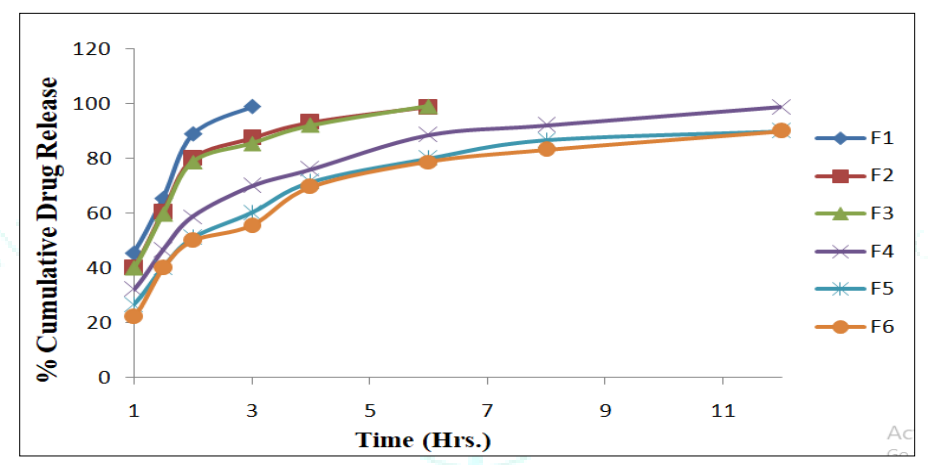

Figure 2 In-vitro drug release study of GRF tablets

Table 6 Regression analysis data of levofloxacin floating matrix tablets

\begin{tabular}{|c|c|c|c|c|}
\hline \multirow{3}{*}{ Batch } & Zero Order & First Order & Higuchi & $\begin{array}{c}\text { Korsmeyer- } \\
\text { Peppas }\end{array}$ \\
\cline { 2 - 5 } & $\mathbf{r}^{\mathbf{2}}$ & $\mathbf{r}^{\mathbf{2}}$ & $\mathbf{r}^{\mathbf{2}}$ & $\mathbf{r}^{\mathbf{2}}$ \\
\hline F4 & 0.788 & 0.989 & 0.916 & 0.946 \\
\hline
\end{tabular}

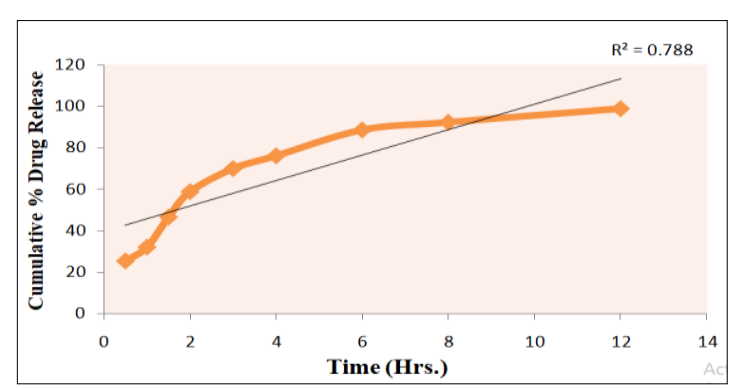

Figure 3 Zero order release kinetics

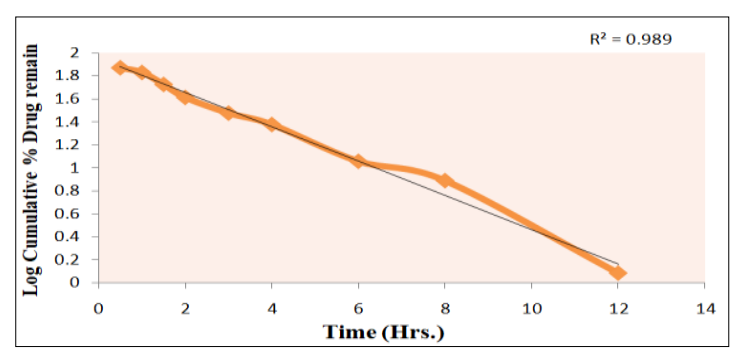

Figure 4 First order release kinetics

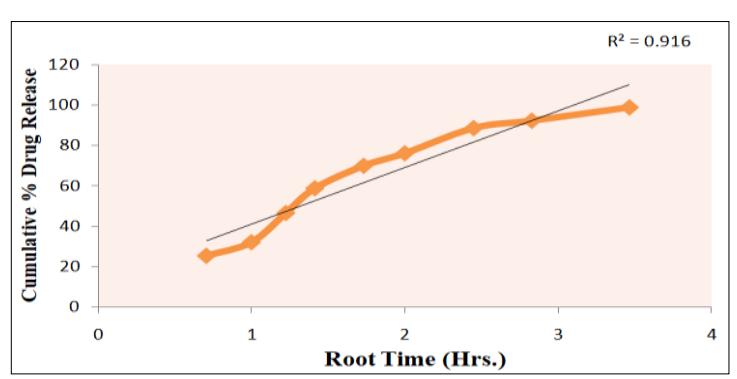

Figure 5 Higuchi release kinetics

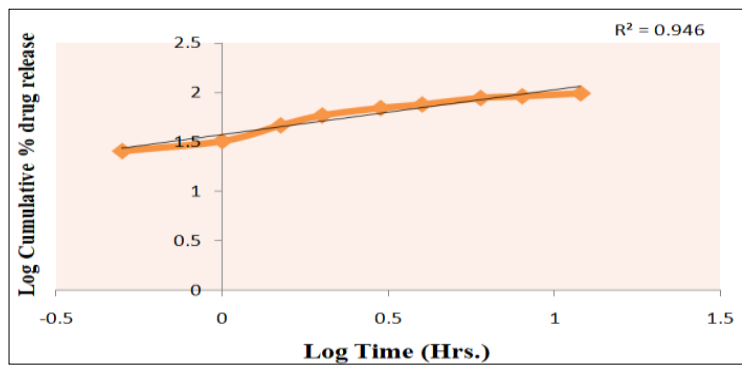

Figure 6 Korsmeyer-Peppas release kinetics 


\section{CONCLUSION}

Gastro-retentive controlled drug delivery system of levofloxacin was prepared to increase the therapeutic effect of the drug by releasing the drug at the proximal part of the small intestine. Levofloxacin is used in eradication of Helicobacter Pylori and other bacterial infections. Levofloxacin floating tablets were prepared using of carbopol and hydroxy propyl methyl cellulose in various ratios by direct compression technique employing sodium bicarbonate as gas-generating agent. According to the above results, formulation $\mathrm{F} 4$ offered best controlled release along total floating time of $12 \mathrm{~h}$ and in-vitro drug release of $98.78 \%$ at the end of $12 \mathrm{~h}$.

\section{REFERENCES}

1. Jimenez-Martínez I, Quirino-Barreda T, Villafuerte-Robles L Sustained delivery of captopril from floating matrix tablets. Int J Pharm 2008; 362:37-43.

2. Arora G, Malik K, Singh I, Arora S, Rana V. Formulation and evaluation of controlled release matrix mucoadhesive tablets of domperidone using Salvia plebeian gum. J Adv Pharm Tech Res 2011;2:163-9

3. Nagaich U, Chaudhary V, Tonpay SD, Karki R. Design and evaluation of a metronidazole central core matrix tablet. J Adv Pharm Tech Res 2010; 1(1):88-96.

4. Sathiyaraj S, Devi RD, Hari VB. Lornoxicam gastro retentive floating matrix tablets: Design and in vitro evaluation. J Adv Pharm Tech Res 2011; 2:156-62.

5. Negi JS, Trivedi A, Khanduri P, Negi V, Kasliwal N. Effect of Bioadhesion on initial in vitro buoyancy of effervescent floating matrix tablets of ciprofloxacin HCl. J Adv Pharm Tech Res 2011;2:121-127.

6. Samyuktha Rani B, Vedha Hari BN, Brahma Reddy A, Punitha S, Devi P, Rajamanickam V. The recent developments on gastric floating drug delivery systems: An overview. Int J PharmTech Res 2010; 2:524-34

7. Yadav A, Jain DK. In-vitro characterization of gastroretentive microballoons prepared by the emulsion solvent diffusion method. J Adv Pharm Tech Res 2010; 1:56-67.
8. Yadav A, Jain DK. Gastroretentive microballoons of metformin: Formulation development and characterization. J Adv Pharm Tech Res 2011; 2:51-5.

9. Thakkar VT, Shah PA, Soni TG, Parmar MY, Gohel MC, Gandhi TR Fabrication and evaluation of Levofloxacin hemihydrates floating tablets. Res Pharm Sci 2008;3:1-8

10. Nelson JM, Chiller TM, Powers JH, Angulo FJ. Fluoroquinoloneresistant campylobacter species and the withdrawal of fluoroquinolone from use in poultry: a public health success story. Clin Infect Dis 2007; 44:977-80.

11. Md Ismail $M$, Dehghan $M H$, Shaikh A, Sahuji T, Chudiwal $P$. Preparation of a novel floating ring capsule-type dosage form for stomach specific delivery. Saudi Pharm J 2011; 19:85-93.

12. Desai S, Bolton S. A floating controlled release system: in-vitro and in-vivo evaluation. J Pharm Res 1993:10; 1321-5.

13. Sakore S, Chakraborty B. Formulation and evaluation of enalapril maleate sustained release matrix tablets. Int J Pharm Biomed Res 2013; 4:21-6.

14. Udayakumar T, Suresh AG, Ubaidulla U. Formulation and evaluation of immediate and sustained release bilayered tablet with glibenclamide and metformin Hcl. Int J Res Dev Pharm Sci 2013;2:337-43.

15. Shashidhar P, Vidya Sagar G, Srikanth G. Design and in-vitro evaluation of metformin hydrochloride (SR) and glimepiride (IR) as bilayered tablets. Int J Pharm Chem Sci 2013; 2:780-92.

16. Sridhar Babu G, Vijay Kumar D, Aishwarya M, Malathy PS, Redya Naik R. Formulation and in vitro characterization of sustained release matrix tablets of metformin Hcl. J Glob Trends Pharm Sci 2014;5:2085-92.

17. Saluja V, Garg C. Once-daily sustained-release matrix tablets of metformin hydrochloride based on an enteric polymer and chitosan. J Pharm Educ Res 2013; 4:92-7.

18. T. Salsa, F. Veiga, M.E. Pina. Oral controlled-release dosage forms. i. cellulose ether polymers in hydrophilic matrices. Drug Dev Ind Pharm. 1997; 23:929-938.

19. Varshosaz J, Tavakoli N, Eram SA. Use of natural gums and cellulose derivatives in production of sustained release metoprolol tablets. Drug Del 20061 13(2): 113-119.

20. ApparaoP, Jyothi, Prabhakarreddy V, Raju J, Shashidher B. Formulation and evaluation of gum based matrix tablets of lamivudine. Der Pharmacia Sinica 2011; 2 (3): 176-192. 